\title{
RESULTS OF THE EXAMINATION OF FIELD CROP SPRAYERS IN THE CONDITIONS OF CENTRAL SERBIA
}

\section{REZULTATI ISPITIVANJA RATARSKIH PRSKALICA U USLOVIMA CENTRALNE SRBIJE}

\author{
Barać $\mathrm{S}^{1}$, Petrović $\mathrm{D}^{2}$, Vuković $\mathrm{A}^{1}$, Biberdžić $\mathbf{M}^{1}$, Đikić $\mathrm{A}^{1}$, Đokić $\mathrm{D}^{3}$ \\ ${ }^{1}$ University of Priština, Faculty of Agriculture, 38219 Lešak, Kopaonicka bb \\ ${ }^{2}$ University of Belgrade, Faculty of Agriculture, 11080 Zemun, Nemanjina 6,Belgrade, \\ ${ }^{3}$ Institute for Forage Crops, 37251 Globoder-Kruševac \\ E-mail: sasa.barac@ikom.rs
}

\section{SUMMARY}

Proper protection and quality work of sprayer enable the optimization of the pesticide application and reduces the harmful effects on the environment and human health. The efficiency of the implemented protection is reflected in several aspects, and one of the most important is the quality of the work of sprayers, that is, the equality of pesticides distribution with nozzles. The paper presents an analysis and comparison of test results in the framework of the inspection of field crop sprayers in the exploitation conditions of central Serbia, in accordance with European standards EN 13790, which prescribes methods and equipment for inspection. The aim of the research was to determine the quality of the work of chests and the uniformity of the flow of various sprays, depending on the defined parameters. The test equipment used "AAMSSALVARANI" measuring equipment, and the flow of the nozzles was measured by the SN S001 individual nozzles. On the basis of the obtained results, it was concluded that the average values of the flow of the sprayer amounted to $0.9541 \mathrm{~min}^{-1}$ (typ A), $1.1691 \mathrm{~min}^{-1}$ (typ B), or until $1.1901 \mathrm{~min}^{-1}$ (sprayer typ C), where the coefficient of variation was in the range $12.24 \%$ to $29.49 \%$.

Key words: spayers, nozzles, application quality, flow, pesticides.

\section{INTRODUCTION}

The limiting factor of effectiveness, economy and the safety of plant protection is the uniform cross distribution of the protective agent. Successful suppression of herbal agents is possible only if protection is based on accurate, rapid and effective application of protective agents (Mahmood, 2003). Despite the critical approach to the use of chemical preparations in plant protection, the application of pesticides to sprayers will continue in the future, with pesticides still in the first place for use in crop protection (Panneton et al., 2001; 2005; Salyani et al. al., 2007; Giles et al., 2008). Bearing in mind that in the Republic of Serbia, according to official data, 138.084 sprayers and 17.281 mitsblowers 
are registered and over $82 \%$ older than 10 years, it is understandable that the control of the correctness and quality of the machines for the application of pesticides is understandable. The optimal spraying of the protective fluid is possible thanks to the common effect of various parts of the sprayer, such as a pump, valves, a distribution system, an automatic control device and, of course, a sprayer. The spreaders determine the size of droplets, the shape and angle of the output jet, the amount of liquid and the quality of covering the sprayed surface (Đukić, et al., 2002). The wrong selection of the sprayer or their poor maintenance, great damage is caused, and in the case of insufficient and incorrect spraying of the protective liquid, the pesticide does not achieve much effect, resulting in significant losses in yield and quality. Due to the application of increasingly rigorous environmental regulations, it is necessary that the pesticide application machines accurately dosage and equally protect protective agents in order to achieve optimal success in plant protection with a minimum dose, while at the same time preserving the environment in a given time frame. The uniformity of liquid distribution is expressed by the coefficient of variation $(\mathrm{CV})$ of the flow of the sprayer, which represents the percentage deviation of the flow of individual sprays from its tabular value: from 1-10\% excellent distribution of 10-12\% - good, from $12-15 \%$ - satisfactory and over $15 \%$ - poor (Urošević et al., 2010). In Serbia, the use of pesticides is further complicated by an inadequate technical level of the application device; testing new machines in operation is generally not enforced, and often operate machines insufficiently trained persons (Sedlar et al., 2007). The quality of the treatment machines for application in relation to the correctness, adaptability, technical solutions and the contemporance of machines affect the accuracy of distribution, dosing accuracy and size of the losses (Bugarin et al., 2008). The most important factor spraying machines represent nozzles. They perform important functions such as leakage of the given amount of liquid per unit time, making disperse liquid droplets of appropriate size and form a stream of appropriate shape (Tadic et al., 2014). Defective nozzles that give a higher or lower flow rate due to worn or clogged need to be replaced with new ones. During the work of the sprayer, as a result of the higher pressures of the application, a greater surface coverage occurs, which is explained by a better disintegration of the working fluid (Sedlar et al., 2013; Bugarin et al., 2012). The exploitation factor of the distribution uniformity of the sprayer is the type of sprayer, the height of the sprayed wings from the treated surface, the speed of movement and the working pressure (Višacki i sar., 2014). At an operating pressure of 2 bar, the flow of sprayer Andric amounted to $0.811 \mathrm{~min}^{-1}$ with a variation coefficient of $7.38 \%$, and a sprayer "Kovin" $1.331 \mathrm{~min}^{-1}$ coefficient of variation 1.01 while at a pressure of 3 bar the flow rate was $1.001 \mathrm{~min}^{-1}$ and $1.611 \mathrm{~min}^{-1}$ (Tadic et al., 2010). With the sprayer ST 12004 at a pressure of 3 bar, the coefficient of variation was $7.79 \%$, or $7.268 \%$ at a pressure of 4 bar (Višacki et al., 2013). Of the 180 tested sprayers, over $20 \%$ did not satisfy the quality of the transverse pesticide rapeseed, with an average flow of $1.581 \mathrm{~min}^{-1}$ with a coefficient of variation of $1.99 \%$ for the sprayer "Mlaz", with a spray coefficient of $1.99 \%$ 'Kovin' '1.61 $1 \mathrm{~min}^{-1}$ with a coefficient of variation of only $0.75 \%$ (Banaj et al, 2014). The introduction of HACCP and "Global GAP" standards in agricultural production guarantees the health safety of products, and the absence of pesticide residues, especially in fresh vegetables and fruits (Koprivica et al., 2015). Examining the quality of the work of six different sprinklers Đokić et al. (2015) indicate that the working fluid flow varied 
from $0.441 \mathrm{~min}^{-1}$ to $1.741 \mathrm{~min}^{-1}$, while the coefficient of variation ranged from $5.131 \%$ to $18.885 \%$.

The research was carried out in order to determine the quality of the work of the various sprayers, in accordance with the European standards EN 13790, which prescribes the methods and equipment for the inspection, which provides the possibility to fulfill the conditions prescribed by the "Global GAP" Standard.

\section{MATERIAL AND METHOD}

Field crop sprayers research was conducted in the framework of inspection control in the exploitation conditions of central Serbia during 2016. They included a visual overview and determination of the general state of the sprinklers and the measurement of the working fluid flow on sprinklers of various sprays depending on the parameters defined. To measure the flow, a single sprayer AAMS-Salvarani S001 was used to measure the flow of all types of sprayers (including pneumatic), mounted on sprinklers, with an accuracy class of 1\%. The AAMS-Salvaged Flow Discharge Analyzer is a handheld tool designed for quick and precise control of the characteristics and wear of the sprinkler, and measurements can also be used for calibration purposes. The tests included three sprayers: Morava Požarevac M-330L (type A) equipped with nozzles Lechler ST 110 03, Morava Požarevac M440L (type B) with nozzles Kovin 11004 and sprayer Agromehanika AGS 330 type (C), with nozzles Hardi 0,2F. Working pressure was 3.0 bar and spray height $0.5 \mathrm{~m}$. All values were read in five reps, and the sprinklers worked in an aggregate with tractors of power greater than $40 \mathrm{~kW}$. During the test, the air temperature was $14^{\circ} \mathrm{C}$, relative humidity $84 \%$, and the wind speed occasionally on the boom was in the range of $0.5-3.7 \mathrm{~m} \mathrm{~s}^{-1}$. The obtained results were statistically processed and display graphic. The technical characteristics of the investigated field sprayers are shown in Table 1 .

Tab. 1. Technical characteristics of the tested sprayers

Tab. 1. Tehničke karalteristike prskalica

\begin{tabular}{|c|c|c|c|}
\hline \multirow{2}{*}{ Parameters - Parametri } & \multicolumn{3}{|c|}{ Type of sprayers- Tip prskalice } \\
\hline & $\mathrm{A}(\mathrm{M}-330 \mathrm{~L})$ & B (M440L) & $\mathrm{C}(\mathrm{AGS} 330)$ \\
\hline Volume of the tank - Zapr. rezervoara & 330 & 440 & 330 \\
\hline Pump type - Tip pumpe & MP 60 & MP 60 & BM 65/30 \\
\hline Pump capacity - Kapacitet pumpe & 60 & 60 & 65 \\
\hline Pump pressure - Pritisak pumpe & 20 & 20 & 30 \\
\hline $\begin{array}{l}\text { Power to pump the pump- Potrebna snaga za } \\
\text { pogon pumpe }\end{array}$ & 2,4 & 2,4 & 4,0 \\
\hline Number of membranes - Br.membrana & 2 & 2 & 2 \\
\hline Max. rpm & 550 & 550 & 550 \\
\hline Work width - Širina rad. zahvata & 8 & 8 & 8 \\
\hline Required tractor power- Potrebna snaga traktora & $>30$ & $>30$ & $>30$ \\
\hline Aggregation mode- Način agregatiranja & \multicolumn{3}{|c|}{ Rear mounted sprayer } \\
\hline Type of nozzles- Tip rasprskivača & LechlerT11003 & Kovin 11004 & Hardi F 0,2 \\
\hline Number of nozzles- Broj rasprskivača & 16 & 16 & 16 \\
\hline Work pressure- Radni pritisak & 3 & 3 & 3 \\
\hline Treatment angle- Ugao tretiranja & $80-110$ & $80-110$ & $80-110$ \\
\hline
\end{tabular}




\section{RESULTS AND DISCUSSION}

On the basis of the obtained results, it can be observed that at least the flow values are observed by the sprayer in general, measured in the type A spraying device and amounted to $0.5461 \mathrm{~min}^{-1}$, and the largest sprinkler type $\mathrm{C}$ was $1.61 \mathrm{~min}^{-1}$.

In Charts 1-3 are presented results of the measured volume flows of the working fluid in $1 \mathrm{~min}^{-1}$ by the width of the workload of the tested sprinklers (y).

The arithmetic mean fluids were $0.9541 \mathrm{~min}^{-1}, 1.1691 \mathrm{~min}^{-1}$ and $1.1901 \mathrm{~min}^{-1}$ for sprayers of types A, B and C, and were represented by a full thick line.

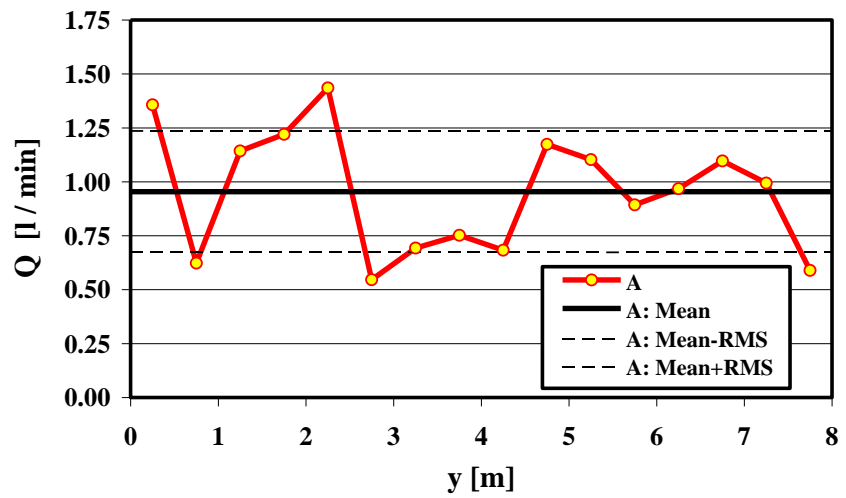

Fig. 1. Liquid flow rate distribution over the working width of the sprayer type A [1 $\left.\mathrm{min}^{-1}\right]$ Sl. 1. Raspodela protoka radne tečnosti po širini radnog zahvata prskalice tipa A [ $\mathrm{min}^{-1}$ ]

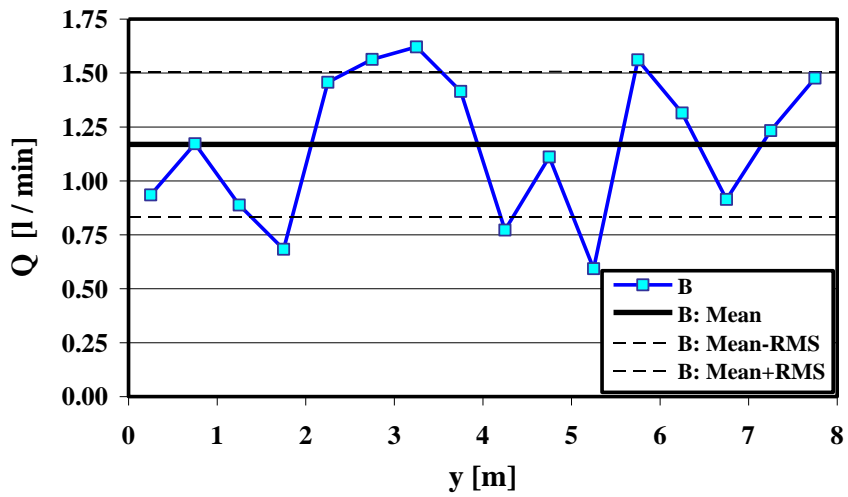

Fig. 2.Liquid flow rate distribution over the working width of the sprayer type $\mathrm{B}\left[1 \mathrm{~min}^{-1}\right]$ Sl. 2. Liquid flow rate distribution over the working width of the sprayer type $B$ [ $\left[\mathrm{min}^{-1}\right]$

Thin intermittent lines denote the boundaries defined by the arithmetic mean and the standard deviations (following the Anglo-Saxon terminology, often referred to as our so-called RMS values), which amounted to $0.2851 \mathrm{~min}^{-1}, 0.3371 \mathrm{~min}^{-1}$ and $0.1461 \mathrm{~min}^{-1}$. Standard deviation represents the absolute measure of dissipation of experimental data 
around the mean (arithmetic mean). Its values were approximately identical for sprayers of types A and B, while in the case of the latter (type C) the standard deviation was about two times lower. This clearly indicates a more even distribution of the working fluid in the last tested sprayer. The same conclusion is derived from the variation coefficient analysis, as a relative measure of data variation, which amounted to $29.49 \%$ for the type A spraying device, $28.82 \%$ for the type B sprayer and $12.24 \%$ for type C. Thus, in this case, the values for the first two sprayers are approximate, while the spray type $\mathrm{C}$ has a coefficient of variation about two times lower. Based on this result, we can notice that sprayers of type $\mathrm{C}$ worked better in terms of the uniformity of the distribution of the working fluid over the width of the workload, compared to the sprayers of type A and B.

Charts 1, 2 and 3 show the absolute values of the flow rate $\mathrm{Q}\left[1 \mathrm{~min}^{-1}\right]$ per working width, which was $8 \mathrm{~m}$ for all three tested sprayers.

The results shown clearly show that the sprayers worked with different norms, since the average flow rates of the deposited working fluid had different values: 0,954 1 $\mathrm{min}^{-1}, 1,1691 \mathrm{~min}^{-1}$ and 1,190 $1 \mathrm{~min}^{-1}$ for sprayers of types A, B and C respectively.

Therefore, in order to further verify the conclusions drawn, the so-called normalization of experimental data. The absolute values of the working fluid flow rate per individual sprinkler $\mathrm{Q}\left[1 \mathrm{~min}^{-1}\right]$ are translated into relative, or percentage points of the same flow Q [\%] in relation to the total spray flow (all sprinklers are collectively). Thus, the fictitiously balanced total flows of all three sprayers, which now amount to 100 [\%].

By the same procedure, the basic descriptive statistical parameters of the distribution of the working fluid in terms of the width $(y)$ of the operation of the tested sprinklers were also calculated.

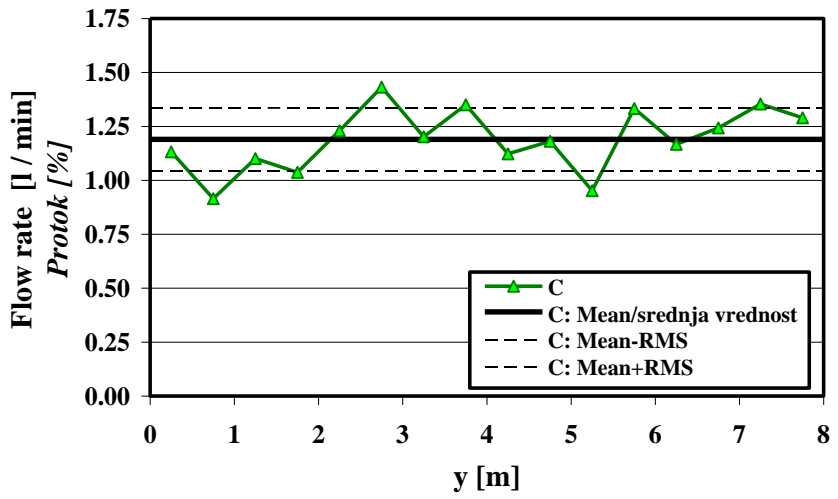

Fig. 3. Liquid flow rate distribution over the working width of the sprayer type $\mathrm{C}$ [ $\left.1 \mathrm{~min}^{-1}\right]$ Sl. 3.Raspodela protoka radne tečnosti po širini radnog zahvata prskalice tipa C [l $\left.\mathrm{min}^{-1}\right]$

Graph 4 shows the percentage (normalized) flow rate Q [\%] of the working width of the tested sprinklers of $8 \mathrm{~m}$. 


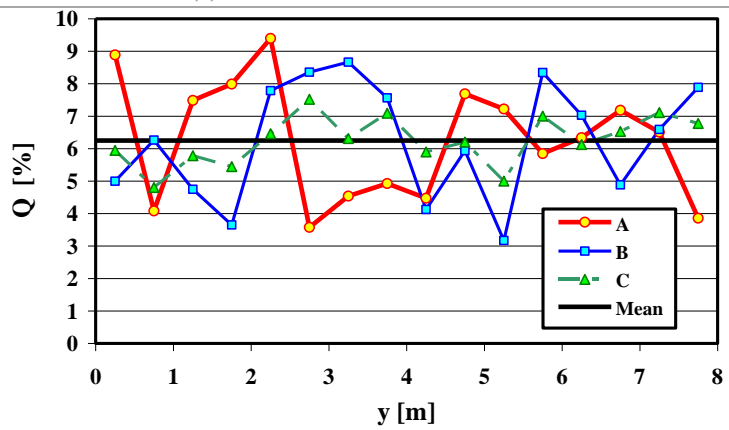

Fig. 4. Percentual distribution of the flow rate of the working fluid through the nozzles, over the working width of the sprayer type $\mathrm{A}, \mathrm{B}$ and $\mathrm{C}\left[1 \mathrm{~min}^{-1}\right]$, with respect to total volumetric flow of the sprayer

Sl. 4.Procentualna raspodela protoka radne tečnosti na rasprskivačima, po širini radnog zahvata prskalica tipa $A, B$ i $C$, u odnosu na ukupni zapreminski protok

With this approach, the average flow rate of the working fluid is identical for all three sprayers and is determined as the ratio of the total percentage flow $(\mathrm{Q} \Sigma=100[\%])$ and the number of nozzles equal to all three sprayers $(n=16)$ :

$$
\bar{Q}=\frac{Q_{\Sigma}}{n}=\frac{100[\%]}{16[-]}=6,25[\%]
$$

Normalized flow rates, reduced to the percentage level of total fluid flow, allow comparison of the tested sprayers. For these values, the corresponding standard deviations (RMS) were calculated, which amounted to 1.843 for type A spraying, 1.802 for type B sprayer and 0.765 for spray $C$ respectively.

Corresponding representations of the percentage distribution of liquids, with corresponding mean values increased and decreasing for the corresponding RMS values are shown in figures 5-7. Their analysis unambiguously confirms the previous conclusion on the superiority of the sprayer type $\mathrm{C}$ in relation to the other two types of sprayers (A and $\mathrm{B}$ ).

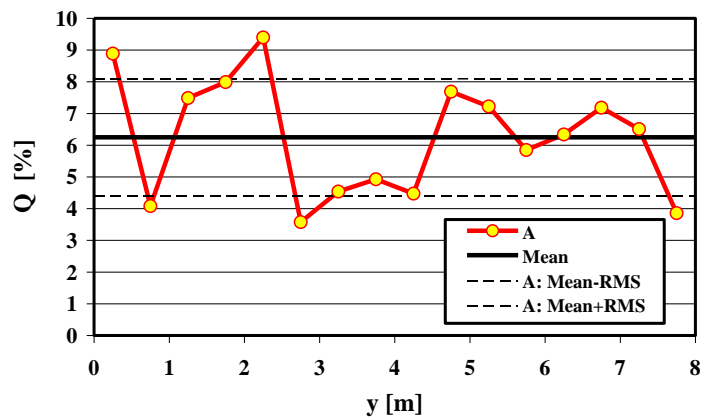

Fig. 5.Percentual distribution of the flow rate of the working fluid through the nozzles, over the working width of the sprayer type A [ $\left.\mathrm{min}^{-1}\right]$, with respect to total volumetric flow of the sprayer

Sl. 5. Procentualna raspodela protoka radne tečnosti na rasprskivačima, po širini radnog zahvata prskalice tipa A u odnosu na ukupni zapreminski protok 


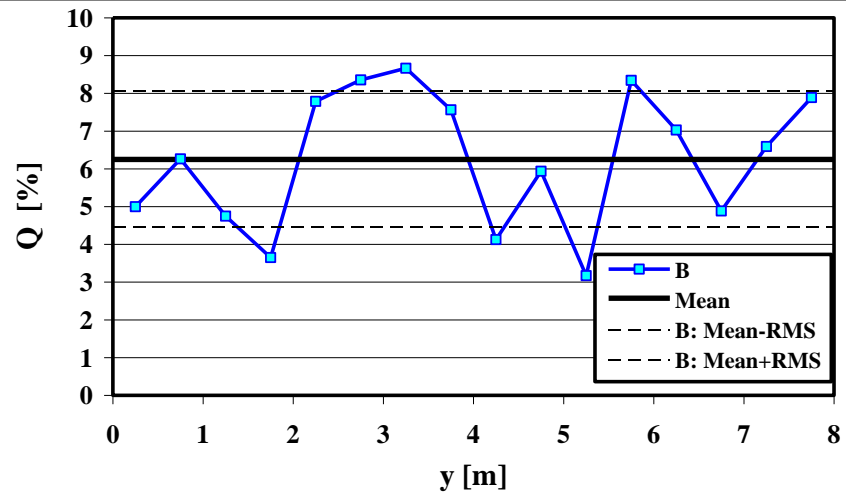

Fig. 6. Percentual distribution of the flow rate of the working fluid through the nozzles, over the working width of the sprayer type $\mathrm{A}\left[1 \mathrm{~min}^{-1}\right]$, with respect to total volumetric flow of the sprayer

Graf. 6. Procentualna raspodela protoka radne tečnosti na rasprskivačima, po širini radnog zahvata prskalice tipa $B$ u odnosu na ukupni zapreminski protok

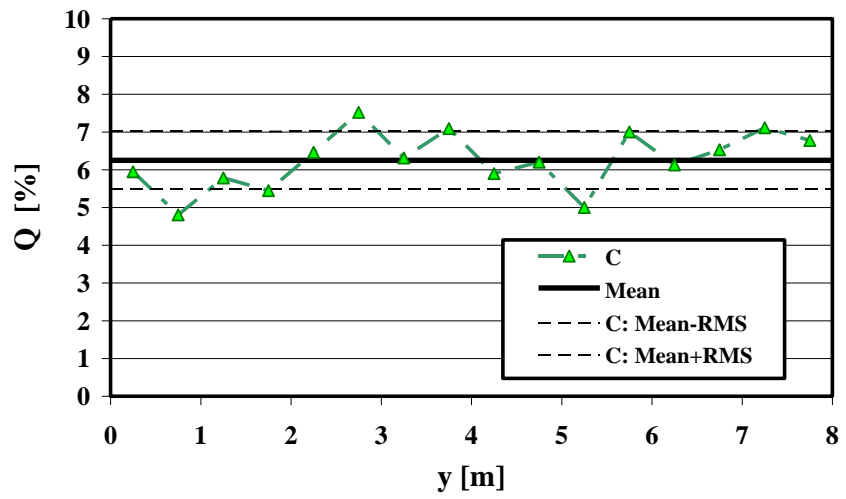

Fig. 7. Percentual distribution of the flow rate of the working fluid through the nozzles, over the working width of the sprayer type $\mathrm{C}\left[1 \mathrm{~min}^{-1}\right]$, with respect to total volumetric flow of the sprayer

Sl. 7. Procentualna raspodela protoka radne tečnosti na rasprskivačima, po širini radnog zahvata prskalice tipa $C$ u odnosu na ukupni zapreminski protok

\section{CONCLUSION}

Proper protection and quality work of sprayers enables the optimization of the pesticide application and reduces the harmful effects on the environment and human health. On the basis of the obtained results, it can be concluded that at least the flow values were observed by the nozzles in general, measured with spray type A, amounting to $0.5461 \mathrm{~min}^{-1}$, and the largest in the sprinkler type $\mathrm{C}$ and amounted to $1.61 \mathrm{~min}^{-1}$. The results shown clearly show that the sprayers achieved different norms because the average flow rates of the deposited working fluid on the nozzles were of different values. In the case of a sprayer type A, an average flow of $0.9541 \mathrm{~min}^{-1}$ (Lechler ST11003 sprayers) 
was achieved with sprayer type B of $1.1691 \mathrm{~min}^{-1}$ (Kovin 11004 nozzles), while a mean flow of $1.1901 \mathrm{~min}^{-1}$ (Hardi F 0.2). Standard deviation values were approximately the same for sprayers of types A and B, while in the case of the last sprayer (type C) the standard deviation was about two times smaller. This clearly indicates a more even distribution of the working fluid in the last spray test. The same conclusion is also derived from the analysis of variation coefficients, which amounted to $29.49 \%$ for type A sprayer, $28.82 \%$ for type B sprayer and $12.24 \%$ for type C. Based on this result, we can conclude that sprayer of type $\mathrm{C}$ are better worked with regard to the uniformity of the distribution of the working fluid by the width of the workload, compared to sprayers type A and B.

\section{REFERENCES}

[1] Banaj Đ, Tadić V, Jurković D, Seletko N. (2014): Spray Distribution With Field Nozzles. Proceedings of 45th Croatian \& 5th International Symposium on Agriculture, Opatija, Croatia, pp 1214-1218.

[2] Bugarin R, Đukić N, Sedlar A. (2008): Factors for efficient use in the protection of perennial plantations with mist blowers. Contemporary Agricultural Engineering, 34(3-4): 236-243. (In Serbian).

[3] Bugarin R, Sedlar A, Milovac Ž, Jakupović J. (2012): Quality of oil seed rape treatment with different type of nozzles on sprayers. Contemporary Agricultural Engineering, 38 (4): 357-366. (In Serbian).

[4] Đokić D, Vasić Tanja, Milenković Jasmina, Terzić D, Stanisavljević R, Barać S, Koprivica R. (2015): The system of regular tehnical device control for the application of pesticides in the Republic of Serbia. Proceedings of Sixth International Scientific Agricultural Symposium "Agrosym 2015", Jahorina, Bosnia and Herzegovina, HerzegovinaHepp. 930-935.

[5] Đukić N, Sedlar A. (2002): Hidro-pneumatska tehnika u zaštiti ratarskih i povrtarskih kultura; Savremena poljoprivredna tehnika, 28(3-4):88-96. (In Serbian).

[6] Giles D. K, Akesson N. B, Yates W. E. (2008): Pesticide application technology: research and development and the growth of the industry. Transactions of the ASABE. Vol. 51:397-403.

[7] Koprivica R, Veljković Biljana, Barać S, Đokić D. 2015: Importance attesting device for applications plant protection products. Proceedings of the XX Symposium on biotechnology with international participation. Faculty of Agronomy. Čacak, Serbia, 20 (22): pp $601-605$. (In Serbian).

[8] Mahmood, R. K. (2003): Development of a test bench for performance evaluation of locally developed nozzles for a sperayer. M.Sc. (Hons) Thesis of Agricultural Engineering, Department of Farm Machinery \& Power, Faculty of Agricultural Engineering \& Technology, University of Agriculture, Faisalabad, Pakistan.

[9] Panneton B, Theriault R, Lacasse B. (2001). Efficacy evaluation of a new spray recovery sprayer for orchards. Transactions of the ASAE, $44: 473-479$.

[10] Panneton B, Lacasse B, Piche M. (2005). Effect of air-jet configuration on spray coverage in vineyards. Biosystems Engineering, 90:173-184. 
[11] Salyani M, Farooq M, Sweeb R. D. (2007). Spray deposition and mass balance in citrus orchard applications. Transactions of the ASABE, $50: 1963-1969$.

[12] Sedlar A, Đukić N, Bugarin R. (2007). First inspections mist blowers in Serbia. Contemporary Agricultural Engineering, 33(1-2): 12-19. (In Serbian).

[13] Sedlar A, Bugarin R, Višacki V, Zoranović M, Milovac Ž. (2013). Parallel research of oil seed rape quality and efficacy treatment with different nozzle type. Contemporary Agricultural Engineering, 39 (2): 77-84.

[14]Tadić V, Banaj Đ, Banaj Željka (2010 ): Spray Distribution With Field Nozzles Made of Brass. Proceedings of 45th Croatian \& 5th International Symposium on Agriculture, 2010, Opatija, Croatia, pp.1219-1223.

[15]Tadić V, Banaj Đ, Petrović D, Knežević D., Seletković N. (2014). Testing tehnical system in plant protection in Republic of Croatia. Proceedings of the 42nd. International Symposium on Agricultular Engineering, Zagreb, Croatia, pp 161-166.

[16]Urošević M, Živković M, Vukša P. (2010). Parameters of sprinclers explotation potential for crop production. Agricultural Engineering, 36(3):95-100. (In Serbian).

[17]Višacki V, Sedlar A, Bugarin R, Turan J. (2013): The effect working pressure onm the distribution uniformity of a nozzles. Contemporary Agricultural Engineering, 39 (2): 85-92. (In Serbian).

[18]Višacki V, Sedlar A, Turan J, Bugarin R, Burg P. (2014): Pesticide application uniformity with most frequent parameters of exploitation. Contemporary Agricultural Engineering, 40(3): 125-134. (In Serbian). 


\title{
REZULTATI ISPITIVANJA RATARSKIH PRSKALICA U USLOVIMA CENTRALNE SRBIJE
}

\author{
Barać S $\mathbf{S}^{1}$, Petrović $\mathrm{D}^{2}$, Vuković $\mathrm{A}^{1}$, Biberdžić $\mathbf{M}^{1}$, Đokić $\mathrm{D}^{3}$
}

\section{SAŽETAK}

Pravilnom zaštitom i kvalitetnim radom prskalica omogućuje se optimizacija aplikacije pesticida i smanjuje štetni uticaj na životnu sredinu i zdravlje ljudi. Efikasnost izvedene zaštite ogleda se sa više aspekata a jedan od najznačajnijih je kvalitet rada prskalica, odnosno uniformnost distribucije pesticida rasprskivačima. Rad predstavlja analizu i upoređenje rezultata ispitivanja u sklopu inspekcijske kontrole ratarskih prskalica u eksploatacionim uslovima centralne Srbije, u skladu sa evropskim normama EN 13790 koji propisuje metode i opremu za obavljanje inspekcije. Cilj istraživanja je bio da se utvrdi kvalitet rada prsaklica i uniformnost protoka različitih rasprskivača u zavisnosti od definisanih parametara. Za ispitivanje je korišćena merna oprema "AAMSSALVARANI", a protok rasprskivača je meren pomoću ispitivača pojedinačnih rasprskivača SN S001. Na osnovu dobijenih rezultata zaključeno je da su prosečne vrednosti protoka rasprskivača iznosile $0,9541 \mathrm{~min}^{-1}$ (tip A), 1,169 $1 \mathrm{~min}^{-1}$ (tip B), odnosno 1,190 $1 \mathrm{~min}^{-1}$ (tip C), pri čemu je koeficijent varijacije bio u rasponu 12,24\% do $29,49 \%$.

Ključne reči: prskalica, rapsrkivač, kvalitet aplikacije, protok, pesticidi.

Acknowledgement: This research was supported by the Serbian Ministry of Science and Technological Development - projects "Improvement of biotechnological procedures as a function of rational utilization of energy, agricultural products productivity and quality increase" (Project no. TR 31051).

Primljeno: 21. 02. 2017. god.

Prihvaćeno: 02. 03. 2017. god. 